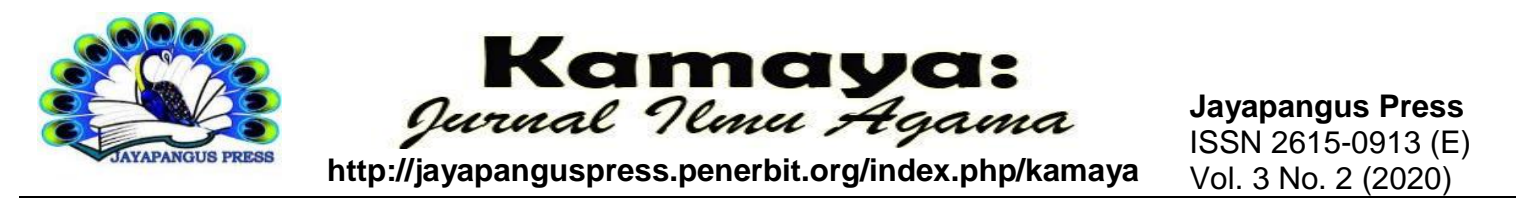

\title{
Dynamics Of The Priest Symbol At Hindu Community In Mataram City
}

\author{
By: \\ Ni Gusti Ayu Made Mawartini' ${ }^{1}$, Ida Ayu Vista Dewi², Ni Nengah Ditya Riskika Dewi \\ Ni Gusti Ayu Nyoman Putriani ${ }^{4}$ \\ ${ }^{1234}$ Sekolah Tinggi Agama Hindu Negeri Gde Pudja Mataram \\ ${ }^{2}$ dayuvista@gmail.com
}

\begin{tabular}{l}
\hline Keywords: \\
\hline Dynamics; \\
Symbols; Priest; \\
Religious \\
Practice; Hindu \\
\hline
\end{tabular}

\begin{abstract}
This study aims to conduct a study of the dynamics in the priest symbol at Hindu community in Mataram city. This study focuses on issues relating to how the description, what is the function, how is the impact, and what is the meaning of the dynamics in the priest symbol at Hindu community Mataram city? This research was designed in an interpretive descriptive study using a case study model. Data collected by observation, interview and documentation techniques. Data were analyzed with data reduction techniques, data display, and data verification. Data validity is checked using credibility, transferability and confirmability testing techniques. Based on the results of the study, it was found that the dynamics of the priest symbol in Mataram city underwent a change which initially used the maśiwa-buddha symbol lately there was a tendency towards the use of the priest sarwa Sadhaka. The impact of the dynamics in the priest symbol in Mataram has the tendency to cause two phenomena, namely social segregation and social polarization. The meaning of the dynamics of the priestly symbol consists of religious, theological, ethical, mystical, social, cultural and economic solidarity.
\end{abstract}

\begin{tabular}{|c|c|}
\hline Kata Kunci: & Abstrak \\
\hline $\begin{array}{l}\text { Dinamika; } \\
\text { Simbol: }\end{array}$ & Penelitian ini bertujuan untuk melakukan kajian terhadap \\
\hline Kependetaan; & $\begin{array}{l}\text { alnamika dalam simbol kependetaan pada masyarakat Hindu dl } \\
\text { Kota Mataram. Penelitian ini memokuskan permasalahan }\end{array}$ \\
\hline Praktik & berkaitan dengan bagaimana deskripsi, apa fungsi, bagaimana \\
\hline Hindu. & $\begin{array}{l}\text { dampak, dan apa makna dinamika sistem simbol kependetaan } \\
\text { pada masyarakat Hindu di Kota Mataram? Penelitian ini }\end{array}$ \\
\hline & $\begin{array}{l}\text { dirancang dalam penelitian deskriptif interpretatif dengan } \\
\text { menggunakan model studi kasus. Data dikumpulkan dengan } \\
\text { teknik observasi, wawancara dan dokumentasi. Data dianalisis }\end{array}$ \\
\hline
\end{tabular}


dengan teknik reduksi data, display data, dan verifikasi data. Keabsahan data dicek dengan teknik pengujian kredibilitas, transferabilitas dan konfirmabilitas. Berdasarkan hasil penelitian ditemukan bahwa dinamika simbol kependetaan di Kota Mataram mengalami perubahan yang awalnya menggunakan simbol masiwa-budha belakangan ini ada kecenderungan penggunaan simbol pendeta sarwa Sadhaka.. Fungsi dinamika simbol kependetaan di Kota Mataram, yaitu untuk memberikan pengetahuan dan pengembangan terhadap tugas dan wewenang seorang pendeta. Dampak dari dinamika sistem simbol kependetaan di Kota Mataram bertendensi menimbulkan dua fenomena, yaitu segregasi sosial dan polarisasi sosial. Makna dari dinamika simbol kependetaan terdiri dari makna religius, teologis, etis, mistis, solidaritas sosial, kultural dan ekonomis.

\section{Introduction}

Practicing religious teachings in world life is supported by several elements such as scriptures, religious holy days, holy people and holy places. All these elements/components are interrelated in fostering religious life. The deepening and appreciation of religion can not only be done by studying the teachings, or carrying out worship in holy places, but the saints are needed, wise people to guide, so as not to deviate too far from the nature of the teachings of Hinduism. In Hinduism asserted that those who have the authority to lead a yajña are saints/wise men, who in their lives have carried out physical and spiritual purification through a padiksan and pawintenan ceremony. People who have performed padiksan and pawintenan ceremonies are called pandita and pinandita.

The existence of a saint in Mataram city has a very influential dynamics for the lives of Hindus in carrying out religious life in the community. The view of the existence of a pedanda, which is divided into three, namely the pedanda Siwa, the pedanda Budha, and the bhujangga. Pedanda Siwa and Pedanda Budha since the arrival of the Balinese people to Lombok in the historical period were used as symbols of priests in the implementation of Hinduism. Lately there have been a number of priests who were ordained by Hindu-based clans, such as the Pasek community who ordained Pandita Mpu as priests, as well as the Pande clan using Sri Mpu to lead religious rituals even though they still brought in from Bali. 
The presence of a number of priest symbols from various clans in Mataram city refers to Wirawan (2006) as a movement towards a change in the priest symbol. This can be seen from the original use of the symbol of students to become a symbol consisting of priests from various clans. This phenomenon is a representation of a priest who has a Sarwa Sadhaka identity. The priest symbol used by Hindus in Mataram city in the historical period used priests from the brahmana wangsa (descendants of the brahmana) group, while the presence of priest symbols from various clans provided an opportunity for the emergence of the use of priests with the identity of Sarwa Sadhaka.

The above phenomenon is a representation of the dynamics in the priest symbols which are indicated by changes in the use of priesthood symbols which were initially limited to the brahmana wangsa group, but later have opened up opportunities for ordination of priest symbols originating from various clan elements. These conditions are very interesting to study, especially those related to efforts to see the systematics in carrying out the dynamics of the priest symbol, the dynamics function, the impacts it causes, and the meaning contained therein. In this regard, this research is very important to find answers four of formulations problems. First, how is the dynamics of the priest symbol in the Hindu community in Mataram city. Second, what is the function of the dynamics in the priest symbol in the Hindu community in Mataram city? Third, what is the impact of the dynamics in the priest symbol on the Hindu community in Mataram city ? Fourth, what is the meaning of the dynamics in the priest symbol in Hindu communities in Mataram city?

\section{Method}

The design of this study in the form of interpretative qualitative. Referring to Margono (2010) qualitative research is research that focuses more attention on the formation of substantive theories based on concepts arising from empirical data. The approach of this study uses descriptive qualitative approaches. Descriptive qualitative methods which is used aims to describe the dynamics of the priest symbol, namely from originally using the symbol of maśiwa-budha to the symbol of Sarwa Sadhaka.

This research was conducted in the midst of religious life in Hindus in the city of Mataram. The type of data obtained from this study is interactive qualitative data. Qualitative data is data in the form of words or in the form of verbal statements, not in the form of numbers. The type of data obtained from this research is interactive qualitative 
data. Qualitative data is data in the form of words or in the form of verbal statements, not in the form of numbers. The method used in this study is the Ethnographic Method. Among the general models of research used by social scientists, ethnography is the same as anthropology and specifically the function of structural theories that are prescriptive in nature. Ethnography is related to the concept of culture (cultural concept). Thus ethnography is an analysis of the description or reconstruction of images in culture and groups (reconstruction of intact cultural scenes and groups). Ethnogarafis studies (ethnographic studies), namely describing and interpreting culture, social groups or systems.

The data source is a combination of primary data and secondary data. Primary data is data obtained directly from informants or informants and from observations made by researchers in the field. Primary data is original data from research data sources (Iqbal, 2002). Primary data in this study are data sourced from informants who know about the origin and existence of the pedanda Siwa and pedanda Budha in Mataram. Criteria in determining the informant as the source of primary data in this study, namely: (1) People who understand something through the process of enculturation so that something is not only known but also lived among those who understand about Hindus saints, public figures, Hindu figures or scientists who understand the teachings of Hinduism; (2) People from the area who are chosen randomly (random); (3) People who were initially classified as unfamiliar to researchers so that it was more exciting to be a guest speaker; (4) People who have the time to provide information in a comprehensive manner and do not tend to convey information subjectively. Secondary data is data obtained from documents, such as monographs, statistical data, manuscripts, publication results and research reports from agencies or agencies as well as other supporting data sources. Secondary data is also data collected from existing sources. Secondary data in this study are all supporting information obtained from references that are relevant to the object of study in this study.

According (Sukmadinata, 2007) in general there are several data collection techniques, namely observation, interviews and documentation studies. Observation (observation) is a technique or way of collecting data by observing observations of ongoing activities. In this study, using participatory observation methods. Participatory observation methods can be described as methods of observation in which the researcher positions himself as a participant as others being observed. Interview is a form of communication conducted by two or more people that involves someone who wants to 
obtain information from others by asking questions based on specific objectives. The interview is used as a data collection technique if the researcher already knows with certainty that the informant is used as a source of information to be obtained (Sugiyono, 2013). The document is a record of events that have passed. Documents can be in the form of writing, drawings, recordings or other works. Sukmadinata (2007) states the study of documentation (documentary) is a data collection technique by collecting and analyzing documents, both written documents, images and electronics. In this study using the literary documentation method with the aim of getting in-depth information about the object of study by researchers. The documentation method is used to support the data obtained by observation and interview techniques. The documents collected in this study are photographs of the dynamics of the priest symbol in the Hindu community in Mataram city and so on.

\section{Results And Discussion}

\section{Description of the Dynamics of Hindu Priest Symbols in Mataram City}

Based on the texts of a number of Hindu literatures, the diksa have the right to receive all ceremonies/yajñas, both routine (nityam ekayajña) and those of a work nature (anityam ekayajña). Related to that, muput is meant to be able to complete yajñas in religious ceremonies from a small level (nista) to a large level (uttama), such as ngarga tirtha which means to make or "give" with the puja of the place for the ceremony. The implementation of Hinduism in the city of Mataram in carrying out a large ceremony using the sign of the pedanda Siwa and the pedanda Budha for muput (leading the implementation of the ritual). The implementation of large-scale Hindu religious ceremonies has similarities with the implementation of Hindu rituals in Bali, such as Tawur Kasanga, Panca Walikrama, Eka Dasa Rudra usually use the symbols of masiwabudha or who are capable of being the pedanda Siwa nad pedanda Budha. This priest has special authority as follows:

a. Pedanda Siwa: as a purifier or purifying nature of the akasa. Through his admiration, the Siwaberwenang regent is dedicated to uploading the solar studio, which means offering yajña from the natural world up and down. Siwaberasal Pandanda from the Shiva School. It means that the Siwam pedagogue has the ability to purify nature above and reduce the power of Sang Hyang Widhi. 
b. Pedanda Budha: offer or set the yajña to the middle or the awang-awang. Pedande Budha berasal from the Buddhist school who has the expertise to purify the middle world and bring the holy power of Sang Hyang Widhi (God Almighty) to the power of Bhuta - which has been nyomya (neutralize) underworld.

At present the community carries out a large ceremony that is raised by Sulinggih (Hindu priest) from their respective communities called sarwa Sadhaka. Sarwa Sadhaka are all Sulinggih that are ordained from various clans / communities. Thus at this time there are many Sulinggih and begin to understand that all priest are the same, all priest must be able to lead. All Hindu priests from any clan may initiate themselves to be Hindu spiritual leaders or become Sulinggih /priest. From the priests there are pedanda Siwa, pedanda Budha, Sri Mpu, Pandita Mpu, and other priest symbols, all of the Sulinggih are the same and his names from the clan are to indicate where he came from.

Siwa-Budha is a term for priests who are the masters of the Siwa sect, and the Buddhist sect, which is in charge of leading a series of large religious ceremonies in Mataram. Of the various sects that have flourished in the city of Mataram, these two sects are the largest and are still influential today. According to the hereditary tradition in Mataram, only brahmana wangsa priest can lead these ceremonies. However, because the appointment of priests as the ceremonial leader was very caste-like, a rectification effort was undertaken by the younger generation of Hindus. They assumed that all priests who fulfilled their sanctity qualifications could lead the ceremony, regardless of their position and social status in society.

\section{Function of the Dynamic in the Priest Symbol in Hindu Communities in Mataram}

Very many titles or names of Sulinggih . According to (Suhardana, 2006) quotes from a number of lontar (manuscript) about terms that have the same meaning or equivalent to the word Sulinggih, among others: in Lontar Bhuanakosa, Sadhaka or Sulinggih is also called:

a. Receipts that reflect that he is obliged to nourish the holy fire in him.

b. Yati who reminded her about her obligation to achieve success in spiritual life.

c. Wira are aware of the obligation to maintain the firmness of faith.

d. Wiku who showed his obligation in maintaining purity of heart, so that he was always alert.

e. Widhwan who revealed that he has broad insight in inner knowledge. 
f. Yogi, Mahayogi, Yogiswara who stated that he was able to connect atman with paramatman in his efforts to achieve deliverance.

g. Muni, Mahamuni, Muniswara who hinted as people who were obliged to display a godly life.

h. Pandita, Mahapandita who revealed about his obligation to increase the mastery of sacred knowledge in life.

i. Dwijendra, Dwijarajendra who hinted that he had an honorable position because his birth was equipped with holy knowledge.

j. Sadhaka which reflects that he is a person who is obliged to carry out "sadhana" in carrying out life.

k. Tatwawit which implies that life has an obligation to master all kinds of tatwa.

Furthermore, in Lontar Widhisastra Rogasanghara there are two terms that have the same meaning as Sadhaka or Sulinggih, namely:

a. Bhujangga which reflects his obligation as an adherent to Ananta Bhoga through saptapatala in the Soring Haribhawana region.

b. Brahmins reflect their obligations as Brahman worshipers through sapta loka in the Luhuring Akasa region.

Then in Lontar Raja Purana, there are terms that have the same meaning as Sadhaka or Sulinggih, namely:

a. Siwa who suggests that the Sadhaka are Siwa worshipers.

b. Budha which implies that Sadhaka is a devotee of Buda.

c. Sengguhu as Sadhaka who carries out his obligation to foster the people.

d. A dukuh that emphasizes a life that tends towards emptiness.

e. Resi Sewa Sogata which refers to the group Sulinggih or Sadhaka in the popular "triple union" as Tri Sadhaka.

Furthermore, in the Book of the Chronicle of Dalem also found other terms that have the same meaning as Sadhaka or Sulinggih namely:

a. Pandya is Sadhaka or Sulinggih who masters good spiritual knowledge.

b. Мpu which emphasizes its position as community bearer.

c. Dang Hyang is Sadhaka or Sulinggih with an honorable position thanks to his mastery in high spiritual knowledge. 
Two terms that have the same meaning as Sulinggih or Sadhaka are also found in the Book of Dwijendra Tatwa

a. A sign is a Sulinggih who uses a stick, both in the sense of sekala (Sulinggih who uses a stick) and in the sense of niskala (Sulinggih which has a literary stick). Please note that danda means stick.

b. Bhagawan is Sulinggih who is able to achieve happiness thanks to the mastery of high spiritual knowledge.

All of the names are essentially the same, those who have gained a place of honor in the community because of their innate purity.

In terms of authority or division of tasks in the great ceremony of Sulinggih that is used, it is usually the Tri Sadhaka yaitu, the pedanda of Siwa, the pedanda of Buddha and Bhujangga. Pedanda Siwa is as a purifier or purification of the upper space or akasa. Pedanda Siwa originates from the Siwa sect which later became known as the pedanda Siwa. Pedanda Budha offering yajñas to the middle space. Pedanda Budha came from a Buddhist sect which has the expertise to purify the middle space.

This priestly dynamics is seen as a human relations technique, with the aim that the quality of individual relationships within the group can lead to positive behavioral changes. This is done through an andragogy approach where participants are more actively participating in a training program. more to give views to Hindus to experience or carry out activities to solve a problem that is recreational, then the process in a social life can be applied with differences that exist to advance Hindus.

Based on the data obtained, the function of the dynamics of the priestly symbol system includes:

a. Make the cooperation of all Hindus mutually beneficial in terms of overcoming life's problems.

b. Facilitate the work.

c. Solve the problem of divided groups of Hindus, who need solutions to problems and reduce the workload that is too large to finish faster, efficient and effective. One of them is by dividing the tasks of each pandita to adjust the group to each group (according to expertise).

d. Creating a democratic climate in social life by enabling each individual to provide input, interact, and have a high role in society. 
Herbert Blumer and George Herbert Mead were the first to define the theory of symbolic interactionism. Blumer expressed about the three main principles of symbolic interactionism, namely about the meaning (meaning), language (language), and thought (thought). This premise will later lead to the concept of 'one's self' and its socialization to the 'community' which is larger 'society'. Blumer put forward the first premise, that human acts toward people or things on the basis of the meanings they assign to those people or things. That is, humans act or behave towards other human beings basically based on the meaning they put on the other party. The Symbolic Interactionism Theory emphasizes that the socialization of a pastor to Hindus in Mataram together between all priests can enlighten all Hindus that all priests have the same duties and authority.

The function of the dynamics of the priestly symbol in the city of Mataram is to provide knowledge and development of the duties and authority of a priest, but for the development up to now the phenomenon has become more advanced which emphasizes that all priests have the same duties and authority in another sense all pastors must be able to master all.

\section{The Impact of the Dynamics in the Priest Symbol on Hindu Communities in Mataram}

Hindu priests are human beings who have inner eyes and can radiate spiritual authority, and have the sensitivity to receive occult vibrations, in appearance they can manifest tranquility and compassion accompanied by physical and spiritual purity in practicing religious teachings, unaffected by waves of life joy and sorrow. There are two classes of Saint known in Hinduism namely ekajati and dwijati. Saints who have done the dwijati in the Hindu concept of being given the title of pandita or sulinggih are often also given the title sadhaka. Who plays the role of worship of the yajñas practiced by Hindus is a sadhaka who becomes a thinker and has spiritual responsibility for the implementation of the yajña (Agastia \& Subedi, 2020). Sadhaka is a person who always pursues reality, by making efforts to continue spiritual ascent continuously, through the understanding of religious literature, as well as studying it further to be practiced in the interests of the broader community. The sadhaka must not only teach how Hindus draw closer to the Creator (God Almighty), but teach how best to regulate peaceful and harmonious social relations between people and their environment. History has recorded that the philosophy of Tri Hita Karana is a philosophy that has been successfully realized 
as a sacred duty of Hindus to concretize the vertical and horizontal network of life needed in responding to the demands of the times, but success is not a gift that is obtained so easily, but through a long struggle that knows. From some opinions about Hindu priests in the social structure of Hindu society in Bali summarized by Suweta (1991) that what is meant by priests is the same as sulinggih namely a walaka namely a prospective priest who has been confirmed to be a priest through the process of diksa or podgala. In the Balinese social structure, priests are often called Siwa or Surya who are at the top of the structure, while Hindus are generally referred to as sisia who occupy the basis of the structure of the pasiwan.

Every society in daily life will experience a change and experience development. Social groups in a society are also not immune to changes in line with changes in social groups. Good because of changes in the structure of social groups, the change or change of group members, as well as changes in social and economic situations. In general, a social group will also experience changes as a result of changes in the patterns that exist within the group. Conflicts that occur in a particular society will bring changes to the structure of the group, conflict in the community is based on the interests of a group of people which in turn will cause divisions in the community group. Without exception the priesthood symbol which experiences the dynamics of life due to changes in social situations in Hindus in the city of Mataram. The influence of the dynamics of the priest symbol on the people of Mataram has the tendency to cause two phenomena, namely Social Segregation and Social Polarization.

\section{a. Social segregation}

Social segregation can be simply interpreted as a process in which the population experiences compartmentalization. People who experience segregation will form small groups according to their characteristics. The differences in the symbolic of the clergy from each other to form separate groups in the community. Segregation is a cumulative process where there is a starting point. The process of change that was not initially realized, until a segregated settlement emerged, is an example of social dynamics.

The appearance of Hindu priests symbols outside the brahmana wangsa (brahmana clan descendants) should be able to strengthen the Hindu religious practices of each social group because of the presence of a number of priests who come from various clan groups. The more ordained priests the higher the level of enlightenment they should be given so that Hindu awareness to improve religious quality is expected to 
increase. The increase in the quantity of priests who came from various clans should not cause social segregation instead to increase social awareness through intensification of ritual implementation carried out by Hindu communities of various clans. Differences in social groups in the form of clans should not be used as obstacles in realizing social unity. Referring to ( Wirawan \& Widana, 2020) the implementation of religious rituals can increase religious awareness which results in the establishment of social ties. This can be seen from the implementation of traditional rituals that involve adherents of different religions, but can realize social interactions that have the opportunity to realize social harmony. In synergy with that (Kartika, Sastrawan, Fridyantara, \& Wirawan, 2020) expressed that the ritual bapuk dana can also realize the communication of three adherents of different religions that have a positive impact on the realization of a harmonious life among the people who carry out the ritual.

\section{b. Polarization of Community Social Groups}

Polarization can be described as the process of splitting up community units into smaller groups. If you imagine it is almost similar to social segregation. The difference is that polarization is a pattern of division of groups in contrast to each other. For example, wealthy city residents form their own groups. The urban poor also formed their own group. The result is a contrast between rich and poor people in one city.

Functional structural theory sees society as a whole that works to create social order and stability. This theory is often called the functionalism perspective, coined by Emile Durkheim. Durkheim studies a lot about social order and how society can live in harmony. Functionalism focuses on social structures that macro level. This theory confirms that all priests in the Hindu community in Mataram city must be able to unite the people by carrying out their duties and authority together and have the same goal, which is to protect and advance the Hindus.

The dynamics of the priest symbol in Mataram city is divided into two, namely social segregation and social polarization. Social segregation can be simply interpreted as a process where the population experiences compartmentalization while polarization can be described as a process of splitting community units into smaller groups. Where previously every pastor had duties and authority based on his nationality, but for the development up to now the phenomenon has changed more and more based on the understanding of Hindus who are increasingly advanced and assessing all the women have the same duties and authority. 


\section{The Meaning of the Dynamics in the Priest Symbol at Hindu Communities in}

Mataram

Based on field observations, it was found that the dynamics of the priesthood symbol can be analyzed the meaning of the dynamics of the priest symbol in the Hindu community in the city of Mataram. Referring to (Mulyana \& Kharisman, 2015) says that we cannot not communicate (we can't communicate). The statement explains that no human being can live without communication. But not all human behavior is communication. Communication is carried out at various levels of intentionality, from communication that is not intentional at all to communication that is actually planned or realized. Deliberation is not a requirement for communication.

Although we do not intend to convey messages to others, our behavior has the potential to be interpreted by others. We cannot control other people to interpret our behavior. The meaning of this interpretation depends on the physical context, space, time, social and psychological. This context influences the meaning of the communication message. In communicating, a person often uses certain strategies that are considered effective in influencing others.

Communication occurs when someone gives meaning to the behavior of others or his own behavior. Every communication activity has meaning for the communicator. The meaning of communication that occurs is not only interpreted by the communicator, but all people involved in the communication process must interpret the communication in accordance with their respective. In this study the meaning of communication in the dynamics of the priest symbol in the Hindu community in Mataram city was assessed based on the emic meaning of the priest activities in leading the Hindu ritual activities in the city of Mataram. The emic approach in this case does offer something more objective. Because cultural behavior should indeed be studied and categorized according to the views of the person being studied itself. This view can be in the form of a definition given by people who experience an event. Such conceptualization needs to be done and discovered by analyzing the cognitive processes of the people being studied and not forced in the view of researchers.

Referring to Mulyana \& Kharisman (2015) said human perceptions of people, objects or events and their reactions based on their past experiences relating to the person or object. Human perception is also influenced by expectations of the object. This 
statement underlies the interpretation of the dynamics of the priest symbol in the Hindu community in the city of Mataram. The meaning of the dynamics of the priest symbol in the midst of modernization civilization in the Hindu community in Mataram city which has been explored and understood as follows:

\section{a. Religious Meaning}

Nasution (in Titib, 2004) says that religion is closely related to religion. Religion is a recognition of the existence of human relations with supernatural forces that must be obeyed. In an effort to give meaning to the dynamics of the priest symbol carried out by the Hindu community in the city of Mataram, it can be explored and understood that the dynamics of the priest symbol carried out are religiously meaningful to the actors of communication.

In the Theory of Religion proposed by Koentjaraningrat (2007) explains that religion is one part of culture or one of the elements of culture. The religion that underlies someone to do something. Religion is synonymous with rituals performed to invoke something before God. In religion, the most basic thing is a belief in something that is transcendent. The belief about something transcendent was also expressed in the priest activities of the priest in the City of Mataram

The phenomenon of the dynamics of the priest symbol in the Hindu community in Mataram city seemed religious when the dynamics were carried out in the purified area, namely in the temple. This is also shown by the completion of religious ceremonial facilities during priest activities.

\section{b. Theological Meaning}

Many definitions of the term theology, but in essence all the definitions that lead to one understanding, namely knowledge of God. Referring to Suprayogi (in Suetha, 2014), it says literally the word theology comes from Greek, namely from the syllables theos and logos which means divinity. In addition Albert (in Konder, 2009) outlines theology derived from the Greek theos which means God and the suffix ology or logos which means theory, discourse or reasoning. While Augustine (in Donder, 2006) defines theology as derived from Latin theology as reasoning or discussion about God. In addition, explains that theology is the science that talks about God and the relationship with the universe.

Based on the explanation above, theology is supernatural knowledge which is methodical, systematic, and coherent or related to what is believed to be God's revelation 
or related to that revelation. In Hindu theology is known as Brahmawidya. This is based on the Hindu term God called Brahman. Brahman cannot be identified or cannot be conditioned because his creatures are unable to judge Brahman (Purwa, 2012). Humans are only able to identify Brahman into Nirguna Brahman and Saguna Brahman. Saguna Brahman is Brahman which is conditioned or identified with certain functions of Brahman. Every function that is distributed to Saguna Brahman is called a God or Gods. In Hindu theology the people are democratically freed to worship the gods according to the stability of their conscience (atmanastuti). In accordance with the results of observations and collection of documents relating to the dynamics of the priest symbol viewed from theological aspects according to the teachings of Hinduism, the dynamics of the symbol in the revered pastor is God.

\section{c. Ethical Meaning}

Refer to Titib (1999) which revealed that ethics is good and right behavior for the happiness of life and harmonious relations with God, humans and nature. In Hinduism, the teachings of ethics are better known as morality. Ethical teachings in the Vedas include truth, love, non-violence, virtue, perseverance, generosity, noble character, hating bad character, abstinence from gambling, exercising virtue, vigilance, purity, purity, fame, progress, association with noble people, developing character friendly and sweet, prosperous, peaceful, happy, joy, morality, friendship, wiweka, indifference and others. Purwa (2012) says ethics as everything related to goodness and truth. Humans must live with ethics and moral life to maintain the prosperity and peace of the world. The ethics shown by the clergy are proven by being responsible for the people and the ceremonies they lead that have been felt by living beings during the ritual process, namely by completing their duties and authority as a priest.

\section{d. Mystical Meaning}

Mysticism can be understood as the highest existence of human consciousness. This highest awareness lies in the inner or spiritual that affects one's inner behavior $(b h \bar{a} v a)$ and then colors the mindset or vice versa. The mindset has been imbued with the value of mysticism, namely the existence of the inner consciousness. on mental behavior (bhāva) alone, the main thing is bodily behavior. That is, mysticism is not just a theory but rather towards manifestation or practicing mental behavior in the activities of daily living in dealing with fellow human beings and other beings. Religious behavior considers mysticism different from clan attitude, gugon tuhon, stupid, puritanical and 
irrational. Religion as a means of reaching the spiritual level. While spiritual is a high awareness of transcendent values or divinity.

Mysticism is a form of awareness in concrete actions. With the presence of sufficent awareness about things that occur in the supernatural can open our mindsets so that they are able to understand the occult phenomena logically. This makes the spiritual practitioners have the stability not just to believe, but can be said to witness for themselves how the "fine formulas" will work. Between spiritual knowledge and real action should be in line and in rhythm. Mysticism does not matter what the background of the teachings, religion and culture of people who want to live. The mystical meaning in the dynamics of the priest symbol can be analyzed through the finding that a participant can understand mystical events that cannot be understood by the general public.

\section{e. The Meaning of Social Solidarity}

Social solidarity is a form of self-equalization and a form of mutual respect in society. Mutual respect in social life is shown by being together in an activity to help each other. Social solidarity in the dynamics of the priest symbol in Mataram city is evidenced by the togetherness carried out by all the Sulinggih (Hindu priest) from various clans in leading ceremonies and leading people together. The meaning of social solidarity can be analyzed when all the rituals are performed along with the ceremonies performed by Hindus.

The meaning of social solidarity is a collective function of culture. This gives the identity of each individual. In the context of the dynamics of the individual priesthood symbol or ritual performer, the identity of the priest is not only as a Hindu but as a Hindu saint. This form of solidarity gives its own meaning to the dynamics of the priesthood in the Hindu community in the city of Mataram.

\section{f. Cultural Meaning}

Culture is a term that is often used to express about culture. Referring to Widagdho (2008) culture (culture) comes from Latin, namely colere which means to process, do, fertilize and develop. In Dutch the term culture is called culture while in English it is called culture. In the Indonesian perspective, culture comes from Sanskrit from the word buddhayah which is a plural form of the word buddhi which means reason or mind.

Referring to Linton (in Widagdho, 2008) states that culture is a configuration of behavior and the results of behavior whose formation elements are supported and passed on by certain community members. While Koentjaraningrat (in Widagdho, 2008) says 
culture is human behavior and the results of regular behavior by the behavior that must be obtained by learning and all of which are composed in people's lives. Thus it is known that culture is the power of mind in the form of copyright, intention and taste while culture is the result of copyright, intention and taste.

Experts argue that culture has a very essential function for individual and collective human life. Referring to (Geriya, 2008) said that individually culture functions to form a basic personality, self-pride, dignity and human dignity and inner meaning. Collectively, culture functions as the glue of group solidarity, identity giver, qualitative weight and insight in all life of the community, nation and state. In accordance with the law, the existence of culture is dynamic and changing.

These dynamics and changes tend to indicate the regularity of processes and structures so that they can be studied scientifically. Referring to Koentjaraningrat (in Geriya, 2008) said that the process of cultural transformation includes internal factors through the process of cultural evolution and external factors through the process of cultural diffusion and communication. Culture in the form of a priest symbol dynamics characterized by expressive culture with the dominance of religious values, aesthetics and solidarity is a family inheritance, especially priests. This can be seen when the ritual procession is done, a nabe (teacher) will bequeathed knowledge and knowledge about the attendance of his students. The habits and ordinances of a prophet are indicators to be preserved by a priest. The assignment of tasks to students is an indicator that there is a preservation of traditional culture in the activity.

Referring to (Mulyana \& Kharisman, 2015) says culture plays an important role in forming trust. Trust in general can be seen as subjective possibilities that individuals believe. Trust includes objects that are believed by each individual. This culture also emphasizes to each individual about the importance of behavior. From this we can know that the relationship between culture and communication is reciprocal. Both influence each other. Culture cannot live without communication and communication cannot live without culture. Each cannot change without causing change in the other. Likewise the dynamics of the priest symbol in Hindu communities in the city of Mataram. The priest ritual and culture which is a culture of nabe heritage cannot survive without communication. 


\section{g. Economic Meaning}

In the modernization of civilization today, the economy is the most important thing pursued as an effort to fulfill life and lifestyle. Economics is something fundamental for humans today. The problem of unemployment even becomes a very closely related to the economy. Everyone even forgets their other duties and responsibilities for the sake of meeting economic needs. The economic meaning of the dynamics of the priest symbol in the Hindu community in Mataram city can be seen from the freedom of Hindus to determine the ceremonial leader who will lead the ceremonial process to be carried out. The economic meaning can be assessed when in the implementation of the ceremony one can only use one pastor because all pastors must overall control of the duties and authority of a priest.

\section{Conclusion}

Based on the analysis of the dynamics of the priest symbol in Hindu communities in the city of Mataram, the function of the dynamics of the priest symbol and the meaning of the dynamics of the priest symbol in the Hindu community in the city of Mataram, there are several main points of the analysis that can be concluded as follows. First, the dynamics of the priest symbol in the city of Mataram, which previously used the concept of masiwa-budha, using priests from the brahmana wangsa in leading religious ceremonies, now uses the concept of Sadhaka where all clans can ngadegang (ordain) their priests. Previously, every priest had duties and authority based on his clan, but for the development up to now the phenomenon has changed more and more based on the understanding of Hindus that is getting more advanced and assessing all priest have the same duties and authority.

Second, the dynamics function of the priest symbol in Mataram city is to provide knowledge and development of the duties and authority of a priest, but for the development up to now the phenomenon has become more advanced which confirms all pandas have the same duties and authority in another sense all pastors must be able master all the duties and authority. Third, the results of the analysis of the impact of the dynamics of the priest symbol on Hindu society in Mataram city tend to cause two phenomena, namely social segregation and social polarization. Social segregation can be simply interpreted as a process where the population experiences compartmentalization, and 
polarization can be described as the process of breaking up community units into smaller groups.

Fourth, the results of the analysis of the meaning of the dynamics of the priest symbol in the Hindu community in Mataram city found that the meaning of the dynamics of the priest symbol system, namely: (1) the religious meaning is evidenced by the phenomenon of the dynamics of the priest symbol in the Hindu community in the city of Mataram, appearing religious when the dynamics are carried out in the purified area, namely in the temple. This is also demonstrated by the attachment of religious ceremonial facilities during priest activities; (2) the theological significance is proven by praising all manifestations of God in the priesthood ritual, and the priest as an intermediary in leading a ceremonial ritual; (3) the ethical meaning is proven by the manifestation of the responsibility of the pioneer as the ceremonial leader until the completion of the ceremonial ritual activities; (4) the mystical meaning is proven by the ability of a priest in knowing mystical events' (5) the meaning of social solidarity is evidenced by carrying out activities leading the ceremony simultaneously between the pedanda Siwa, pedanda Budha, and Bujangga in a ritual ceremony; (6) the cultural significance is evidenced by the preservation of the pastor's culture which has not changed until now; (7) the economic meaning as evidenced by the similarity in the level of needs or means of a priest in leading the ceremony.

\section{References}

Agastia, I. G. B. D., Perwita, A. A. B., \& Subedi, D. B. (2020). Countering violent extremism through state-society partnerships: a case study of de-radicalisation programmes in Indonesia. Journal of Policing, Intelligence and Counter Terrorism. https://doi.org/10.1080/18335330.2020.1722317

Donder, I. K. (2006). Sisya Sista Pedoman Menjadi Siswa Mulia. Surabaya: Paramita.

Geriya, I. W. (2008). Transformasi Kebudayaan Bali Memasuki Abad XXI. Surabaya: Paramita.

Iqbal, H. (2002). Metodologi Penelitian Dan Aplikasinya. Jakarta: Ghalia Indonesia.

Kartika, K. R., Sastrawan, I. W. D., Fridyantara, N. M. A., \& Wirawan, I. W. A. (2020).

Inter-cultural communication of bapuq dana ritual at multiethnic communities and transreligious. International Journal of Psychosocial Rehabilitation. https://doi.org/10.37200/IJPR/V24I4/PR201017

Koentjaraningrat. (2007). "Manusia dan Kebudayaan Di Indonesia." In Djambatan. https://doi.org/10.1016/s0044-8486(97)00050-1.

Margono. (2010). Doc 21. In Metodologi Penelitian Pendidikan.

Mulyana, I. E., \& Kharisman, R. (2015). Perancangan Alat Peringatan Dini Bahaya Banjir dengan Mikrokontroler Arduino Uno R3. Creative Information Technology Journal. https://doi.org/10.24076/citec.2014v1i3.19 
Purwa, I. K. (2012). Yang Tercecer Dalam Memahami Hinduisme. Denpasar: ESBE Buku.

Sugiyono. (2013). Metode Penelitian Pendidikan (Pendekatan Kuantitatif, Kualitatif, dan $R \& D)$. Bandung: Alfabeta.

Suhardana, K. (2006). Pengantar Etika dan Moralitas Hindu, Bahan Kajian untuk Memperbaiki Tingkah Laku. Denpasar: Paramitha Surabya.

Sukmadinata, N. (2007). Definisi E-learning. Definisi E-learning.

Suweta, I. G. (1991). The situation of cysticercosis/taeniasis in animals/man in Bali. The Southeast Asian journal of tropical medicine and public health.

Titib, I. M. (1999). Pengantar Veda. Surabaya: Paramita Surabaya.

Titib, I. M. (2004). Buku Ajar Psikologi Agama. Jakarta: Direktorat Bimbingan Masyarakat Hindu Dan Budha Departemen Agama RI.

Widagdho, D. dkk. (2008). Dasar Ilmu Budaya. Jakarta: Bumi Aksara.

Wirawan, I. W. (2006). Dinamika dalam Sistem Simbol Kegamaan pada Komunitas Hindu di Kota Mataram, Provinsi Nusa Tenggara Barat. Universitas Udayana.

Wirawan, I. W. A., \& Widana, I. N. M. (2020). Construction of a multicultural civilization in memarek tradition. International Journal of Innovation, Creativity and Change. 